\title{
Effect of Plant Growth Regulators on Morpho-Physiological and Yield Parameters of Some Sesame (Sesamum indicum L.) Cultivars
}

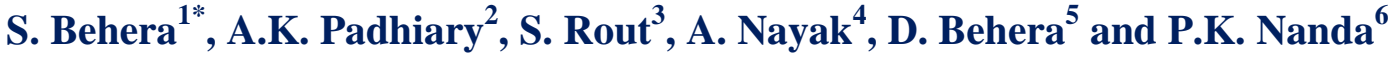 \\ ${ }^{1}$ Krishi Vigyan Kendra, Bhawnipatna, (OUAT), Odisha-766001, India \\ ${ }^{2}$ Krishi Vigyan Kendra, Sambalpur, (OUAT), Odisha-768026. India \\ ${ }^{3}$ College of Forestry, Sam Higginbottom University of Agriculture Technology \& Sciences, \\ Allahabad, Uttar Pradesh-211007, India \\ ${ }^{4}$ Regional Research and Technology Transfer Station, Kalahandi, (OUAT), \\ Odisha-766001, India \\ ${ }^{5}$ College of Agriculture, Bhawnipatna, (OUAT), Odisha-766001, India \\ ${ }^{6}$ Krishi Vigyan Kendra, Keonjhar, (OUAT), Odisha-758002, India \\ *Corresponding author
}

\section{A B S T R A C T}

The present experiment was conducted in the Central farm, OUAT during Rabi season 2014-15 with five sesame varieties viz. Uma, Amrit, Smarak, Prachi and Nirmala to find the efficiency of growth regulators such as NAA, $\mathrm{GA}_{3}$ and IAA in two Conc. (10 ppm and $20 \mathrm{ppm}$ ) sprayed at 30 and 45 DAS. The experiment was laid out in split-plot design with

\begin{tabular}{|l|}
\hline Key w or d s \\
$\begin{array}{l}\text { Cultivars, growth } \\
\text { regulators, physiology } \\
\text { and Sesame }\end{array}$ \\
\hline Article Info \\
\hline $\begin{array}{l}\text { Accepted: } \\
\text { 15 September } 2017 \\
\text { Available Online: } \\
\text { 10 November 2017 }\end{array}$ \\
\hline
\end{tabular}
three replications. The Morpho-physiological observations were recorded at different stages of growth of all the varieties due to effect of growth regulators. Significant increase was observed in response to growth regulator on germination of seeds. The highest percentage of seed germination was recorded in $\mathrm{GA}_{3} 20 \mathrm{ppm}$ (98.51\%). Due to spraying of growth regulators there was increase of plant height, number of branches and leaf area per plant in all the treatments irrespective of varieties and the highest value was exhibited by Nirmala as regards to above characters. The LAI, RGR, NAR, CGR and LAD were found to be increased in PGRs treatments over the control. Among the varieties Nirmala exhibited highest value followed by Amrit. The yield attributing characters such as total dry matter, number of capsules/ plant, number of seeds per capsules and 1000 seed weight were significantly increased among the treatments as well as varieties. Due to the spraying of plant growth regulators the percentage of increase in yield ranged from to a tune of 0.5 $\%$ in $\mathrm{GA}_{3} 10 \mathrm{ppm}$ conc. to $24 \%$ in $\mathrm{GA}_{3} 20 \mathrm{ppm}$ conc. over the control. Among the varieties highest yield was noted in Nirmala (5.60 q/ha) followed by Amrit (5.08 q/ha). In view of the present findings Nirmala was found to be the highest yielder and higher concentrations of plant growth regulators were found to be more significant over the

\section{Introduction}

Sesame (Sesamum indicum L.) adomed as queen of oil seeds. It is commonly known as Til, Gingeli, Sim and it is the oldest important oil seed crop in the tropics. It has been believed as sesame probably originated in Africa. Sesame was introduced into India by the earliest human migrants from Africa, this crop is grown in a period when atmospheric 
evaporative demand is high and availability of irrigation water is low. Under the circumstances there is a need for efficient utilization of water resources or Physiological manipulation of the crop with the growth regulator to overcome the water stress situation (Tian et al., 1993) even through it is grown all over the world for its importance in food, medicine and industries. In the world the major countries producing sesame are china (19.97), Myanmar (16.68), Sudan (9.98) and the countries like Uganda, Nigeria, Pakistan, Ethiopia and Bangladesh contributed less than 5\% in Production. It has been observed that the productivity of sesame in India was $6.76 \mathrm{~kg} / \mathrm{ha}$ as compared to the worlds' average $48.87 \mathrm{~kg} / \mathrm{ha}$. India has leading edge over its area $(29.3 \%)$ and by production $(25 \%)$. Among the oilseed crops sesame ranks $1^{\text {st }}$ for its higher oil content (46$62 \%$ ) with $63.35 \mathrm{k} . c a l / \mathrm{kg}$ of dietary energy in seeds (Kumar and Goel, 1994) the yield of sesame has yield potential of around 20t/ha but low in productivity ( $346 \mathrm{~kg} / \mathrm{ha})$ and hence has tremendous options for management technologies.

Sesame seed provides excellent food nutrition, health care, edible oil and biomedicine. It is digestive, regenerative, antiaging and resource of quality oil. It is rich in Vitamin C, Vitamin A, Vitamin B complex, niacin, minerals like calcium, phosphorous, iron, copper, magnesium, zinc, and potassium. From an industrial point of view sesame is used in manufacturing soaps, cosmetics, perfumes, insecticides and Pharmaceutical Products. Sesame cake is a byproduct of the oil milling industry and valued as livestock feed because of its high methane content. It has been observed as the international market of sesame has been increasing in the recent past due to high demand and various uses. In India Gujarat alone contributed $30 \%$ of total production followed by West Bengal 17.8\%, Rajasthan
$17.6 \%$.West Bengal ranks $1^{\text {st }}$ with $8.6 \mathrm{~kg} / \mathrm{ha}$ followed by Gujarat $5.98 \mathrm{~kg} / \mathrm{ha}$.

In Odisha sesame is cultivated both in Kharif and Rabi season. The average production of sesame is $70.74 \mathrm{Mt}$ during Kharif season where as in Rabi season it is $23.42 \mathrm{Mt}$. During Rabi season sesame is cultivated under nonirrigated situation for which water deficit situation in one of the major abiotic stress which adversely affect the crop growth and yield.

Although many reasons have been attributed to explain such low productivity remain hindrance lies in physiological problems associated with hormonal imbalance which leads to a reduction in the yield of the crop plant growth regulators are known as to change the growth and development pattern of growth plants.

Physiological and biochemical process and thereby increase the yield of the crop. The localized application of some plant growth regulators is reported to have profound effects on assimilate partitioning, enhancing the crop productivity plant growth regulators are effective on several crop plants to balance the source sink relationship and thereby increasing them, they used as an aid to enhance in many crops Indole acetic acid (IAA) and Gibberellic acid $\left(\mathrm{GA}_{3}\right)$ can manipulate a variety of growth and developmental phenomena in various crops.IAA has been found to increase the plant height, number of leaves per plant with consequent enhancement in seed yield in groundnut (Lee,1990) and cotton (Kepgate et al.,1989), it also increases the flowering, fruit set, the total dry matter of crops (Gurudev and Saxena, 1991) likewise $\mathrm{GA}_{3}$ stimulated stem elongation (Harington et al.,1996) increased dry matter accumulation (Hore et al.,1988) and enhance total yield (Deotale et al.,1998). However studies on the effect of growth 
regulators would provide useful information regarding manipulations of growth and yield therefore this experiment was designed to study the effect of IAA, NAA and $\mathrm{GA}_{3}$ in modifying the morphological changes and the yield contributing characters of sesame.

\section{Materials and Methods}

The present experiment entitled "Effect of plant growth regulators on morphophysiological and yield parameters of some sesame cultivars" was conducted at the Central Research Station, Orissa University of Agriculture and Technology, Bhubaneswar, situated at $20^{\circ} 15^{\prime} \mathrm{N}$ latitude and $85^{\circ} 52^{\prime} \mathrm{E}$ longitude of the Department of Plant Physiology, College of Agriculture, OUAT, Bhubaneswar during Rabi 2014-2015. Five sesame varieties viz., Uma, Amrit, Smarak (AVTS-13-9), Prachi, Nirmala (5 Variety) were taken for the study. Breeder seeds of the above varieties were collected from the AICRP on Sesame, OUAT, Bhubaneswar farm for the purpose. A field experiment was conducted with 35 numbers of Field plots which laid out in a complete split-plot Design for 7 treatments and 3 replications (Gomez and Gomez, 1984). The experiment was carried out in the medium land with well drained sandy loam soil and the chemical properties of the soil were analyzed in the Department of Soil Science and Agricultural Chemistry OUAT, Bhubaneswar having $\mathrm{pH}$ (5.4) (Table 2). The data on climatic parameters viz., rainfall, maximum and minimum temperature, relative humidity and bright sunshine hours recorded during the period of investigation (2013-14) at the meteorological observatory, OUAT is depicted in table 1.

Seed treatment was done one day before the sowing on field plot. Seed treatment with saffaya on slurry like water and fungicidal solution and shed dried for 3-4 hours. The crop was grown in Rabi season, 2014-15 using 5 varieties viz., Uma, Amrit, Smarak, Prachi and Nirmala of sesame in a plot size $5.5^{\prime} \times 3.4^{\prime}$ 'with spacing of $30 \mathrm{~cm} \times 15 \mathrm{~cm}$. The meteorological conditions were suitable for raising of crop sesame. Fertilizer was applied @ 40kg N, 20kg $\mathrm{P}_{2} \mathrm{O}_{5}$ and 20 kg K $\mathrm{K}_{2} \mathrm{O}$ along with 10 cartloads of FYM per hectare before sowing of seeds. Two hand weeding was done to keep the crop from weeds and prophylactic plant protection measures were adopted to protect the crop from weeds, diseases and pests attack. The field was irrigated as and when required. Sowing was done manually on $18^{\text {th }}$ Nov 2014, the plots of different treatments were harvested at harvestable maturity stage on $5^{\text {th }}, 7^{\text {th }}$ and $10^{\text {th }}$ March 2015. Seeds after threshing were sun dried to about nine percent moisture level and stored in small cloth bags under ambient condition. The required pre and post-harvest observations were recorded in the laboratory of the department of Plant Physiology. There were seven treatments involving three plant growth regulators (IAA, NAA and $\mathrm{GA}_{3}$ ) applied along with a control. The detail procedures of application of these Plant growth regulators are provided in the following table 1. Foliar application of these plant growth regulators was made at 30 and 45 days after sowing. Observation of the following parameters as per the scheduled before harvesting were recorded at 30, 45, 60 and 90 DAS randomly selected five plants from each plot were collected and the following observations were taken as per the schedule on seed germination and different morpho-physiological characters, i.e., Plant height $(\mathrm{cm})$, Number of Branches per plant, Leaf area per plant, total dry matter, growth analysis parameters [Leaf Area Index (LAI) (Watson, 1952), Crop growth rate (CGR), Relative Growth Rate (RGR) (Leopold and Kriedemann, (1975), Net Assimilation Rate (NAR) (Gregory, 1926), Leaf weight ratio, Specific leaf weight, Leaf Area Ratio (LAR) 
(Gregory,1926), Leaf Area Duration (LAD), Leaf Area Index (LAI) (Watson,1937) and Post-harvest observation i.e., Number of seeds per capsule, number of chaffy seeds per Capsule, number of healthy seeds per capsule, number of capsules per plant, 1000-seed weight, yield (q/ ha), oil content, total dry matter.

\section{Results and Discussion}

The present investigation was carried out at the experimental station of O.U.A.T to assess the effects of growth regulators such as Indole acetic acid (IAA), Naphthalene acetic acid (NAA) and Gibberellic acid $\left(\mathrm{GA}_{3}\right)$ on sesame (Sesamum indicum L.) cultivars.

\section{Morphological characters}

\section{Germination of seeds}

The percentage of germination of seeds as influenced by different growth regulators of different varieties is represented in table 5. Analyzing data it is observed that significant difference on percentage of germination was noted among the different concentration of growth regulator irrespective of varieties. The highest percentage of germination was noted in $\mathrm{GA}_{3}$ 20ppm (98.51) followed by $\mathrm{GA}_{3} 10$ ppm (95.81) whereas the lowest value of the same was observed in control (87.49) $\mathrm{GA}_{3}$ $20 \mathrm{ppm}$ conc. resulted in the maximum increase of germination percentage (12.59) as compared to the control. While examining the effects of growth regulators on germination percentage of different varieties it was observed that highest percentage of germination was noted in Nirmala (95.42) followed by Amrit (93.82). Significant difference among the treatment as well as among the varieties was found as regards to germination percentage. The interaction effect between the variety and the treatment was existed. In the studies of seed germination under different treatments revealed that among all the growth regulators $\mathrm{GA}_{3}$ at both the concentrations (10 and $20 \mathrm{ppm}$ ) resulted higher significant, increases in germination over the control. Besides $\mathrm{GA}_{3}$ other growth regulators such as NAA and IAA of both concentrations also showed an increase in germination percentage of seeds. Seed germination is the resumption of active growth of the embryo that results in the rupture of the seed coat and the emergence of a young plant. Among the growth regulators gibberellic acid controls the germination of seeds more than other PGRs. Presoaking of $\mathrm{GA}_{3}$ results the production of hydrolytic enzymes and multiple forms of amylase such as a $\alpha$-amylase, $\beta$-amylase ribonuclease and 1-3- $\beta-\mathrm{d}$ gluconase which rapidly promote cell wall degradation and digest starch and protein leading to release of energy and nutrients which are essential for germination. Secondly application of exogenous above growth regulators are known to modify the influence of cytokinin transport across membranes and is thus able to initiate the biochemical process necessary for germination, the cytokinin probable penetrates the tet and neutralise the inhibitors present in the embryo, thus enables the embryo to rupture the seed coat, besides this over and above $\mathrm{GA}_{3}$ decreases the total phenol of the seed, so that the percentage of germination was enhanced.(Araby et al., 2009). So the present investigation corroborates the findings of previous workers (Patil and Gaikwad, 2011; Mostafa and Hamd, 2011; Lalitha, 2015).

\section{Plant height}

Data presented in the table 6 revealed that there was minor deviation in plant height at the initial stage of growth (30 DAS) among the treatments. The effect of plant growth regulators on plant height is taken at 45 DAS indicated that highest plant height was recorded from NAA 20 ppm conc. (101.71 
cm) followed by $\mathrm{GA}_{3} 10$ ppm conc. (80.87 $\mathrm{cm})$ and IAA 20 ppm conc. $(80.83 \mathrm{~cm})$ whereas control contributed lowest value of the same $(55.02 \mathrm{~cm})$. The plant height was an increased with increase of growth period. At 90 DAS the highest plant height was observed in $\mathrm{T}_{4}(138.4 \mathrm{~cm})$ followed by $\mathrm{T}_{3}(134.59 \mathrm{~cm})$ with lowest value in $\mathrm{T}_{0}(96.96 \mathrm{~cm})$, similar observation was found among the varieties due to the effect of growth regulators. At 30 DAS highest plant height was recorded from Uma $(40.28 \mathrm{~cm})$ which was significantly increased over all the varieties. At 45, 60, 90 DAS similar trend was recorded. At 90 DAS highest plant height was observed in Uma $(135.30 \mathrm{~cm})$. The percentage of increase at 90 DAS with respect to 30 DAS by Uma, Amrit, Smarak, Prachi, Nirmala was 235.89, 216.30, $237.84,238.54$ and $240.28 \%$ respectively. Significant difference among the varieties and within the treatments was observed. The interaction effect between variety and the treatment was significant.

In general, the growth of the plant was affected by plant growth regulators. Plant height is a manifestation of genetical potential however as sesame is an indeterminate plant, plant height is a beneficial characters to a increase the yield of the crop. However its expression to same degree modified as was evident from a general increase to a tune of $13.03 \%$ in NAA 10 ppm to $42.73 \%$ in $\mathrm{GA}_{3}$ 20 ppm conc. of plant height at 90 DAS. Due to exogenous application of growth regulators irrespective of varieties. A similar increase of plant height has been reported by this may be due to fact that application growth regulators promote the coleoptiles or stem section in rapid and dramatic within 5 to 10 minutes. It causes wall loosening so that water absorption is increased by acid growth hypothesis due to the application of IAA $\mathrm{H}^{+}$ion secrets which lower the $\mathrm{pH}$ so that wall loosening and fast growth occur. Again it is thought that it has the remarkable abilities to activate a plasma membrane ATPase that transport $\mathrm{H}^{+}$from the cytosol in to the wall, to lower the wall $\mathrm{pH}$ so that there will be loosening of cell wall and promote cell growth.it is also thought there will production of protein which involved in growth, the increase of plant height supports the earlier workers (Sontakey et al., 1991) in sesame Lee,1990 in ground nut,Kumar et al.,1996 in okra and Deotale et al.,1998 in soybean, Chauhan et al.,2009 ; Agrawal and Dikshit.,2008.

\section{Number of branches}

The number of branches per plant due to the effect of growth regulators was recorded in table 7 . From the data it was revealed that at 60 DAS highest number of branches per plant was recorded from IAA 20 ppm conc. (3.95) followed by NAA 20ppm conc. (3.65) and $\mathrm{GA}_{3} 20$ ppm conc. (3.62) whereas the lowest value was shown in control (3.34). The percentage of increase ranged from $3.59 \%$ in $\mathrm{GA}_{3} 10$ ppm conc. to $18.26 \%$ in IAA $20 \mathrm{ppm}$ conc. over the control. Significant difference among the treatments was observed. Among the varieties at 60 DAS the highest number of branches per plant was exhibited by Nirmala (4.06) followed by Amrit (3.67) on the contrary the minimum value was observed in Uma (2.88). At 90DAS the same trend was observed among the varieties. The highest number of branches per plant was exhibited by Nirmala (5.90) followed by Amrit (5.58) whereas the minimum value of the same was recorded from Uma (4.65). The interaction effect between variety and the treatment was significant.

A total number of branches per plant increased significantly due to exogenous application of growth regulators at 30 and 45 DAS irrespective of varieties. It was found that the percentage of increase in number of branches per plant was highest in IAA 20 ppm conc. (8.92\%) followed by IAA $10 \mathrm{ppm}$ 
conc. $(8.13 \%)$ due to the inhibitory effect of apical bud upon lateral bud there was more production of branches, the present findings agreed with the previous workers (Awan and Alizal et al., 1989; Sontakey et al., 1991; Sarkar et al., 2002).

\section{Leaf area}

Data on leaf area registered in the table 8 revealed that leaf area recorded at 45 DAS indicated that the highest leaf area (49.76 $\mathrm{cm}^{2}$ ) was exhibited by $\mathrm{T}_{4}$ (IAA $20 \mathrm{ppm}$ ) followed by $\mathrm{T}_{2}\left(48.73 \mathrm{~cm}^{2}\right)$ and $\mathrm{T}_{5}(48.02$ $\mathrm{cm}^{2}$ ) whereas the lowest value was recorded from control $\left(41.76 \mathrm{~cm}^{2}\right)$. A similar trend was recorded in 60 DAS. At 90 DAS the leaf area was decreased irrespective of treatments. The percentage of increase in leaf area ranged from $31.56 \%$ in $\mathrm{T}_{0}$ to $37.22 \%$ in $\mathrm{T}_{2}$ at 60 DAS compared to 45 DAS whereas at 90 DAS the reduction was ranged from $27.06 \%$ in $\mathrm{T}_{0}$ to $37.34 \%$ in $\mathrm{T}_{2}$ compared $60 \mathrm{DAS}$.

At 90 DAS the highest leaf area was exhibited by $\mathrm{T}_{4}\left(42.09 \mathrm{~cm}^{2}\right)$ whereas the lowest value of the same was recorded from $\mathrm{T}_{0}\left(40.07 \mathrm{~cm}^{2}\right)$. Significant difference among the treatments was noted, similar trend was also observed among the varieties. At 45 DAS the maximum leaf area was registered from Nirmala $\left(51.17 \mathrm{~cm}^{2}\right)$ followed by Prachi $\left(48.50 \mathrm{~cm}^{2}\right)$ whereas the minimum leaf area was recorded from Uma $\left(44.05 \mathrm{~cm}^{2}\right)$. As the duration of the crop increased the leaf area increased in the varieties. The percentage of increase of leaf area from 45 DAS to 60 DAS ranged from $33.24 \%$ in Smarak to $37.52 \%$ in Nirmala but at 90 DAS it was $39.98 \%$ in Smarak to $30.53 \%$ in Nirmala as compared 60 DAS. The maximum leaf area was recorded from Nirmala $\left(48.88 \mathrm{~cm}^{2}\right)$ whereas the lowest value of the same was shown in Uma $\left(36.5 \mathrm{~cm}^{2}\right)$.The interaction effect between variety and treatment as well as treatment with variety was found significant.
Leaf area was found to increase significantly in all the varieties when sprayed with PGRs up to 60 DAS ranging from $31.56 \%$ to 37.22 $\%$ and thereafter there was reduction as recorded at 90 DAS ranging from $27.06 \%$ to $37.34 \%$ due to the shedding of leaf. Application of growth regulators enhanced cell division and cell elongation as stated earlier. Due to the application of hormone the hydrolysis of starch, fructose and sucrose increased to from glucose and fructose molecule for which more energy produced, there will be increased of water potential and cell expansion was caused and cell plasticity increased. it promotes leaf growth, so that leaf area is increased Agrawal and Dikshit, (2008) stated that application of IAA,NAA and $\mathrm{GA}_{3}$ increased the number of leaves in pea, the present findings are supported by previous workers (Kokare et al., 2006).

\section{Total dry matter}

The effect of different growth regulators on total dry matter accumulation is reflected in table 9. It was found that due to the effect of growth regulators the dry matter accumulation varied significantly among the treatments. The total dry matter was higher in $20 \mathrm{ppm}$ conc. of each growth regulator. Highest accumulation at 45 DAS was recorded in NAA 20 ppm conc. (1.94 g/plant) followed by IAA $20 \mathrm{ppm}$ conc. (1.93 g/plant). A similar trend was observed at 60 and 90 DAS. At 90 DAS highest total dry matter was observed in IAA 20 ppm conc. (8.43 g/plant) followed $\mathrm{GA}_{3} 20 \mathrm{ppm}(8.04 \mathrm{~g} / \mathrm{plant})$ and NAA $20 \mathrm{ppm}$ $(8.01 \mathrm{~g} / \mathrm{plant})$. The highest percentage of increase over the control was shown in 12.85 $\%$ in IAA 20 ppm conc. followed by $7.63 \%$ in NAA $20 \mathrm{ppm}$ conc. Significant difference among the treatments was observed. Due to the effect of growth regulator among the varieties the maximum dry matter was exhibited by Nirmala (1.98 g/plant) followed by Amrit (1.89 g/plant) at 45 DAS similarly at 
60 DAS and 90 DAS similar trend was recorded. At 90 DAS the highest dry matter was recorded from Nirmala (8.39 g/plant) followed by Amrit ( $8.12 \mathrm{~g} / \mathrm{plant})$ whereas the lowest value was recorded from Uma (7.41 $\mathrm{g} /$ plant), significant difference as regards to dry matter accumulation was observed, the interaction effect between the variety and the treatment was significant.

Application of growth regulators significantly increased the total dry matter accumulation irrespective of varieties due to increasing cell division and other physiological activities, due to the increase of leaf area more photosynthesis are produced and the total dry matter of the plant was increased. The increased of dry matter might be due to the accumulation of building units that accompanied by greater saccharides and protein content which is linked with the photosynthetic operator increasing protein content may be due to the increase in the formation of rough endoplasmic reticulum that provides appropriate medium for increasing the polyribosomes and RNA, the present findings correlates the findings of previous workers (Kokare et al., 2006)

\section{Physiological characters}

The effect of growth regulators affected the physiological characters of different sesame varieties which ultimately determined the yield and yield attributing characters. The following physiological characters were recorded at 90 DAS of the different varieties due to the effect of growth regulators.

\section{Leaf area index (LAI), Relative growth rate (RGR), Leaf area ratio (LAR)}

Data presented on leaf area index (LAI) recorded at 90 DAS is in table 10 which revealed that among the treatments $\mathrm{T}_{6}$ recorded highest LAI 0.097 followed by $\mathrm{T}_{2}$
(0.096), on the contrary the lowest value was exhibited by control (0.092).Among the varieties the highest LAI (0.78) was exhibited by Nirmala followed by Amrit (0.072). The leaf area index was positively correlated with yield $(r=0.984)$ table 16 . The interaction effect between variety and treatment was recorded significant.

The relative growth rate as calculated over a period of 30 DAS (60 DAS to 90 DAS) is represented in table 10. During 60 - 90 days of growth the relative growth rate significantly increased in higher concentration of NAA, GA $\mathrm{G}_{3}$, IAA over the control and highest value was recorded from IAA $20 \mathrm{ppm}$ $(1.654 \mathrm{~g} / \mathrm{g} /$ day $)$ followed by $\mathrm{GA}_{3} 20 \mathrm{ppm}$ $(1.627 \mathrm{~g} / \mathrm{g} /$ day $)$ and the percentage of increase in relative growth rate (RGR) was maximum in IAA 20 ppm conc. (5.14 \%) followed by $\mathrm{GA}_{3} 20 \mathrm{ppm} 3.43 \%$ over the control respectively. Among the varieties highest RGR was recorded from Nirmala (1.750 $\mathrm{g} / \mathrm{g} /$ day) whereas the minimum value of the same was exhibited by Uma (1.499 g/g/day). Significant difference among the varieties in respect to RGR was found. The interaction effect between variety and treatment is significant. There was positive correlation between yield and relative growth rate $(\mathrm{r}=$ 0.981). Data registered in table 10 indicated that there was increase of LAR in all the treatments irrespective of varieties and maximum value was recorded from IAA 20 ppm conc. $\left(79.70 \mathrm{~cm}^{2} / \mathrm{g}\right)$ followed by NAA $20 \mathrm{ppm}$ conc. $\left(78.66 \mathrm{~cm}^{2} / \mathrm{g}\right)$ which was 5.75 $\%$ and $4.71 \%$ increased over the control. Nirmala exhibited highest value of LAR $\left(82.65 \mathrm{~cm}^{2} / \mathrm{g}\right)$ followed by Amrit (80.93 $\mathrm{cm}^{2} / \mathrm{g}$ ). From the table 10 it was found that there was significant difference among the varieties and treatment was exist. The interaction effect of effect between varieties and treatments was existed. There was positive correlation between yield and LAR ( $\mathrm{r}$ $=0.927$ ). 
Leaf weight ratio (LWR), Specific leaf weight (SLW) Specific leaf area (SLA)

From table 11 it was found that irrespective treatments there was an increase of LWR over the control, highest leaf weight ratio was observed in IAA $20 \mathrm{ppm}(0.576 \mathrm{~g} / \mathrm{g})$ with an increase of $6.86 \%$ over the control. Among the variety Nirmala recorded highest LWR $(0.595 \mathrm{~g} / \mathrm{g})$ followed by Amrit $(0.567 \mathrm{~g} / \mathrm{g})$ due to the effect of growth regulator. Significant difference among the variety and treatments were recorded.From table 16, it was noted that there was a positive correlation $(\mathrm{r}=0.897)$ between yield and LWR. The specific leaf weight (SLW) due to the effect of different growth regulators recorded at 90 DAS is presented in table 11 which showed a significant increase over the control irrespective of varieties. It was found that crop sprayed with higher conc. of growth regulators contributed higher SLW as compared to the respective lower concentration of NAA, GA 3 and IAA. Highest SLW was noted from Nirmala $\left(0.298 \mathrm{~g} / \mathrm{m}^{2}\right)$ followed by Amrit $\left(0.269 \mathrm{~g} / \mathrm{m}^{2}\right)$ with lowest value of the same recorded from Uma (0.149 $\mathrm{g} / \mathrm{m}^{2}$ ). The interaction effect on SLW between variety and treatment was found to be significant. There was a positive correlation between SLW and yield $(r=0.978)$ (Table 16). At 90 DAS the effect of different growth regulators of different varieties in specific leaf area (SLA) had been studied which was presented in table 11. It was revealed from the data that higher concentration of different growth regulators showed lower specific leaf area (SLA) as compared to lower concentration of respective growth regulator. The maximum SLA was recorded from control $\left(1.490 \mathrm{dm}^{2} / \mathrm{g}\right)$ whereas the lowest value was showed in IAA $20 \mathrm{ppm}$ conc. $\left(1.434 \mathrm{dm}^{2} / \mathrm{g}\right)$ with reduction of $3.75 \%$ compared to the control. Among the varieties the highest value of SLA was recorded from Uma $\left(1.505 \mathrm{dm}^{2} / \mathrm{g}\right)$ whereas minimum value of the same was observed from nirmala $\left(1.437 \mathrm{dm}^{2} / \mathrm{g}\right)$ with reduction of $4.51 \%$ to the former. It was found that there was negative correlation $(r=-0.236)$ between the SLA with yield and yield attributing characters. The interaction effect on SLA between variety and the treatment was found to be significant.

\section{Crop growth rate (CGR) Net assimilation} rate (NAR) and Leaf area duration (LAD)

At 90 DAS the effect of growth regulators of different varieties on crop growth rate (CGR) had been studied which is presented in table 12. It was revealed from the data that there was increase of CGR in all the concentration of growth regulators as compared to control. The maximum value of CGR was recorded from IAA $20 \mathrm{ppm}$ conc. $\left(52.09 \mathrm{~g} / \mathrm{m}^{2} /\right.$ day $)$ followed by $\mathrm{GA}_{3} 20 \mathrm{ppm}$ conc. (51.81 $\mathrm{g} / \mathrm{m}^{2} /$ day). The percentage of increase in CGR was ranged from $4.84 \%$ in NAA $10 \mathrm{ppm}$ conc. to $14.76 \%$ in IAA 20 ppm conc. Significant difference among the treatments in respect to CGR was found. Among the varieties the highest value of CGR was found in Nirmala $\left(48.91 \mathrm{~g} / \mathrm{m}^{2} /\right.$ day $)$ followed by Amrit $\left(48.60 \mathrm{~g} / \mathrm{m}^{2} /\right.$ day $)$. The interaction effect between the variety and treatment was significant. CGR is positively correlated with grain yield. $(\mathrm{r}=0.946)$ (Table 16$)$. Data reflected in table 12 indicated that significant increase in NAR was recorded in all the treatment of PGRs irrespective of varieties. The maximum increase was observed in $\mathrm{T}_{6}$ $(46.19 \%)$ whereas minimum value of the same was shown in $\mathrm{T}_{1}(4.56 \%)$ over the control. The variety Nirmala exhibited highest NAR $(97.4 \mathrm{mg} / \mathrm{dm} 2 /$ day) followed by Amrit $\left(95.0 \mathrm{mg} / \mathrm{dm}^{2} /\right.$ day) but the lowest value was recorded from Smarak $\left(67.4 \mathrm{mg} / \mathrm{dm}^{2} /\right.$ day $)$. Significant difference within the treatment as well as within variety was noted. The interaction effect between variety and treatment was found NAR is positively correlated with yield $(r=0.893)$ on table 16 . 
Table.1 Meteorological data at the experimental site

\begin{tabular}{|c|c|c|c|c|c|c|c|}
\hline \multirow{3}{*}{ Month } & \multicolumn{2}{|c|}{ Avg. Temp } & \multicolumn{2}{|c|}{ Avg. Rh (\%) } & \multirow{3}{*}{$\begin{array}{c}\text { Bright } \\
\text { sunshine } \\
\text { hours } \\
\text { (BSH) }\end{array}$} & \multirow{2}{*}{\multicolumn{2}{|c|}{ Rain Fall }} \\
\hline & \multirow{2}{*}{ Max. } & \multirow{2}{*}{ Min. } & \multirow{2}{*}{ Morning } & \multirow{2}{*}{ Afternoon } & & & \\
\hline & & & & & & $\mathrm{mm}$ & Days \\
\hline November & 30.9 & 18 & 90 & 44 & 7.2 & 0.0 & - \\
\hline December & 27.7 & 13.9 & 88 & 45 & 5.8 & 0.0 & - \\
\hline January & 27.8 & 14.2 & 91 & 43 & 6.7 & 21.5 & 2 \\
\hline February & 32.5 & 17 & 94 & 39 & 8.3 & 18.4 & 1 \\
\hline March & 35.8 & 21.5 & 91 & 40 & 8 & 24.8 & 3 \\
\hline
\end{tabular}

Table.2 Soil properties of the experimental field

\begin{tabular}{|c|c|c|}
\hline Sl. No. & Particular & Percentage of composition \\
\hline 1 & Texture & Sandy loam \\
\hline 2 & $\mathrm{pH}$ & 5.4 \\
\hline 3 & Total nitrogen & $17.8\left(\mathrm{~kg} \mathrm{ha}^{-1}\right)$ \\
\hline 4 & Available $\mathrm{P}$ & $110.3\left(\mathrm{~kg} \mathrm{ha}^{-1}\right)$ \\
\hline 5 & Available $\mathrm{K}$ & \\
\hline
\end{tabular}

Table.3 Varieties used five

\begin{tabular}{|l|c|}
\hline Name of the Varieties & Symbol \\
\hline UMA & $\mathrm{V}_{1}$ \\
\hline AMRIT & $\mathrm{V}_{2}$ \\
\hline SMARAK (AVTS-13-9) & $\mathrm{V}_{3}$ \\
\hline PRACHI & $\mathrm{V}_{4}$ \\
\hline NIRMALA & $\mathrm{V}_{5}$ \\
\hline
\end{tabular}


Table.4 Details of plant growth regulators application

\begin{tabular}{|c|c|c|c|c|}
\hline $\begin{array}{r}\text { Sl } \\
\text { No. }\end{array}$ & $\begin{array}{c}\text { Treatment } \\
\text { symbol }\end{array}$ & Micronutrients & $\begin{array}{c}\text { Concentration/ } \\
\text { Dose of } \\
\text { Application }\end{array}$ & $\begin{array}{c}\text { Mode of } \\
\text { application }\end{array}$ \\
\hline 1 & $\mathrm{~T}_{0}$ & Control & & - \\
\hline 2 & $\mathrm{~T}_{1}$ & NAA & @ 10 PPM & Foliar Spray \\
\hline 3 & $\mathrm{~T}_{2}$ & $\overline{N A A}$ & @ 20 PPPM & Foliar Spray \\
\hline 4 & $\mathrm{~T}_{3}$ & $\mathrm{GA}_{3}$ & @ 10 PPM & Foliar Spray \\
\hline 5 & $\mathrm{~T}_{4}$ & $\mathrm{GA}_{3}$ & @ 20 PPPM & Foliar Spray \\
\hline 6 & $\mathrm{~T}_{5}$ & IAA & @ 10 PPM & Foliar Spray \\
\hline 7 & $\mathrm{~T}_{6}$ & IAA & @ 20 PPPM & Foliar Spray \\
\hline
\end{tabular}

Table.5 Effect of NAA, GA 3 and IAA on germination percentage on seeds of different Sesame cultivars

\begin{tabular}{|c|c|c|c|}
\hline & Treatment & \multicolumn{2}{|c|}{ Germination percentage } \\
\hline & $\mathrm{T}_{0}$ & \multicolumn{2}{|c|}{87.49} \\
\hline & $\overline{\mathrm{T}_{1}}$ & \multicolumn{2}{|c|}{93.18} \\
\hline & $\mathrm{T}_{2}$ & \multicolumn{2}{|c|}{93.61} \\
\hline & $\mathrm{T}_{3}$ & \multicolumn{2}{|c|}{95.81} \\
\hline & $\mathrm{T}_{4}$ & \multicolumn{2}{|c|}{98.51} \\
\hline & $\mathrm{T}_{5}$ & \multicolumn{2}{|c|}{93.96} \\
\hline & $\mathrm{T}_{6}$ & \multicolumn{2}{|c|}{94.31} \\
\hline & Mean & \multicolumn{2}{|c|}{93.84} \\
\hline \multicolumn{4}{|c|}{ Varieties } \\
\hline & $\overline{V_{1}}$ & \multicolumn{2}{|c|}{93.05} \\
\hline & $\mathrm{V}_{2}$ & \multicolumn{2}{|c|}{93.82} \\
\hline & $\mathrm{V}_{3}$ & \multicolumn{2}{|c|}{93.17} \\
\hline & $\mathrm{V}_{4}$ & \multicolumn{2}{|c|}{93.73} \\
\hline & $\mathrm{V}_{5}$ & \multicolumn{2}{|c|}{95.42} \\
\hline & Mean & \multicolumn{2}{|c|}{93.83} \\
\hline & $\mathrm{SE}(\mathrm{m}) \pm$ & C.D. at 5\% & CV\% \\
\hline $\mathrm{V}$ & 0.017 & 0.057 & 0.086 \\
\hline $\mathrm{T}$ & 0.015 & 0.044 & 0.064 \\
\hline VxT & 0.028 & 0.083 & \\
\hline $\mathrm{TxV}$ & 0.035 & 0.09 & \\
\hline
\end{tabular}


Table.6 Effect of NAA, GA3 and IAA on plant height of different sesame cultivars

\begin{tabular}{|c|c|c|c|c|}
\hline Treatment & 30 DAS & 45 DAS & 60 DAS & 90 DAS \\
\hline $\mathrm{T}_{0}$ & 37.02 & 55.02 & 79.9 & 96.96 \\
\hline $\mathrm{T}_{1}$ & 36.9 & 66.47 & 92.83 & 109.6 \\
\hline $\mathrm{T}_{2}$ & 37.14 & 75.96 & 103.25 & 125.76 \\
\hline $\mathrm{T}_{3}$ & 36.82 & 80.87 & 105.98 & 134.59 \\
\hline $\mathrm{T}_{4}$ & 37 & 101.71 & 119.51 & 138.4 \\
\hline $\mathrm{T}_{5}$ & 36.61 & 78.19 & 96.24 & 129.06 \\
\hline $\mathrm{T}_{6}$ & 37 & 80.83 & 95.63 & 128.41 \\
\hline Mean & 36.93 & 76.80 & 99.05 & 123.25 \\
\hline \multicolumn{5}{|l|}{ Varieties } \\
\hline $\mathrm{V}_{1}$ & 40.28 & 85.34 & 106.25 & 135.3 \\
\hline $\mathrm{V}_{2}$ & 36.54 & 75.14 & 93.69 & 115.58 \\
\hline $\mathrm{V}_{3}$ & 35.46 & 75.78 & 94.22 & 119.8 \\
\hline $\mathrm{V}_{4}$ & 36.22 & 77.19 & 96.47 & 122.62 \\
\hline$\overline{V_{5}}$ & 36.14 & 76.8 & 104.62 & 122.98 \\
\hline Mean & 36.92 & 78.05 & 99.05 & 123.25 \\
\hline DAS & & $\mathrm{SE}(\mathrm{m}) \pm$ & C.D. at 5\% & CV\% \\
\hline \multirow{4}{*}{30} & $\mathrm{~V}$ & 0.18 & 0.6 & 2.28 \\
\hline & $\mathrm{T}$ & 0.17 & 0.50 & 1.87 \\
\hline & VxT & 0.32 & 0.93 & \\
\hline & $\mathrm{TxV}$ & 0.4 & 1.13 & \\
\hline \multirow{4}{*}{45} & $\mathrm{~V}$ & 0.29 & 0.96 & 1.73 \\
\hline & $\mathrm{T}$ & 0.16 & 0.47 & 0.82 \\
\hline & VxT & 0.35 & 1.05 & \\
\hline & $\mathrm{TxV}$ & 0.37 & 1.05 & \\
\hline \multirow{4}{*}{60} & $\mathrm{~V}$ & 0.12 & 0.40 & 0.58 \\
\hline & $\mathrm{T}$ & 0.11 & 0.33 & 0.46 \\
\hline & VxT & 0.21 & 0.62 & \\
\hline & $\mathrm{TxV}$ & 0.26 & 0.74 & \\
\hline \multirow{4}{*}{90} & $\mathrm{~V}$ & 1.44 & 4.70 & 5.37 \\
\hline & $\mathrm{T}$ & 1.77 & 5.02 & 5.57 \\
\hline & VxT & 3.05 & 8.89 & \\
\hline & $\mathrm{TxV}$ & 3.97 & 11.22 & \\
\hline
\end{tabular}


Table.7 Effect of NAA, GA3 and IAA on number of branches of different Sesame cultivar

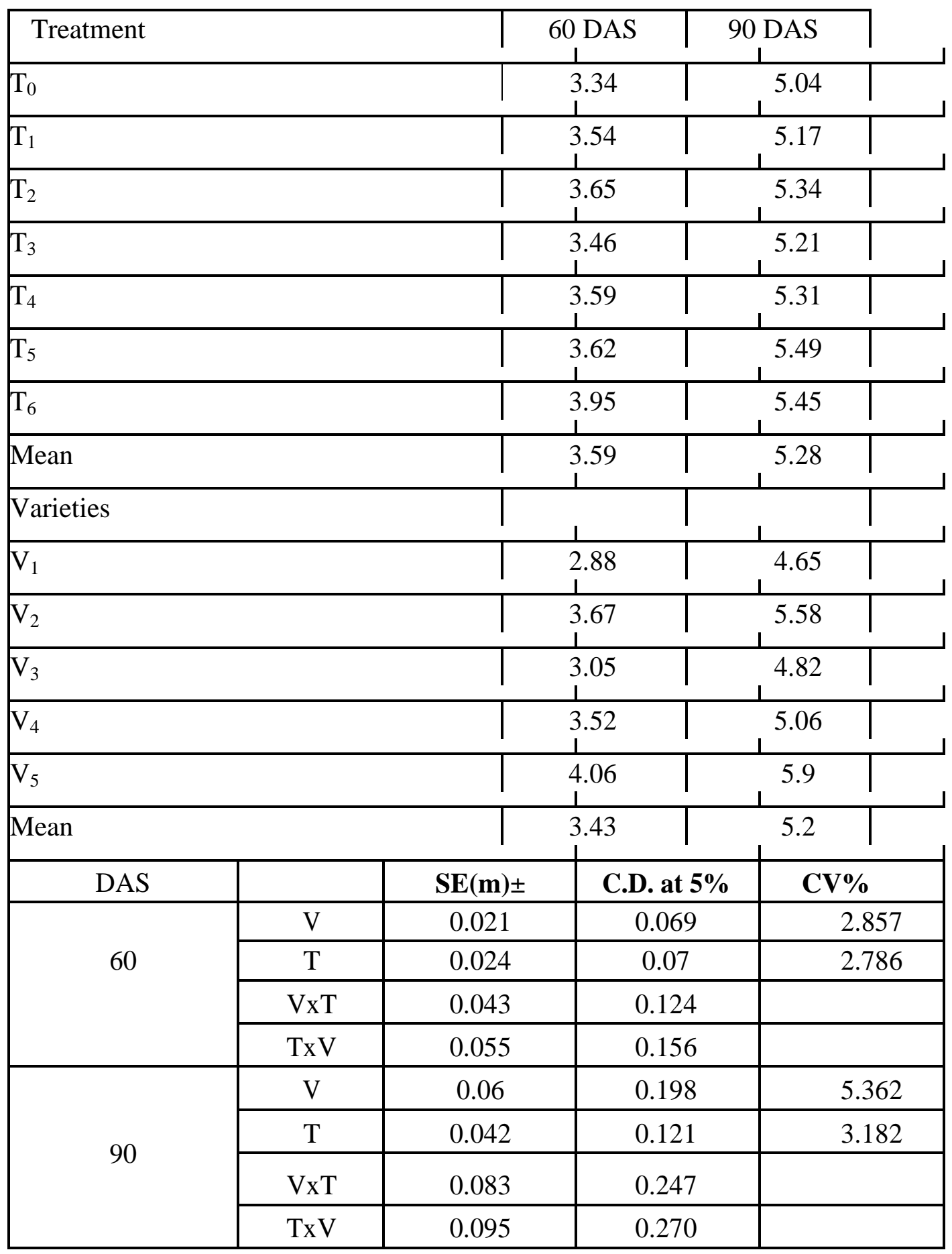


Table.8 Effect of NAA, GA3 and IAA on leaf area per plant $\left(\mathrm{cm}^{2}\right)$ of different sesame cultivars

\begin{tabular}{|c|c|c|c|c|}
\hline Treatment & & 45 DAS & 60 DAS & 90 DAS \\
\hline $\mathrm{T}_{0}$ & & 41.76 & 54.94 & 40.07 \\
\hline $\mathrm{T}_{1}$ & & 47.76 & 64.12 & 41.47 \\
\hline $\mathrm{T}_{2}$ & & 48.73 & 66.87 & 41.9 \\
\hline $\mathrm{T}_{3}$ & & 47.93 & 64.82 & 41.43 \\
\hline $\mathrm{T}_{4}$ & & 49.76 & 66.93 & 42.09 \\
\hline $\mathrm{T}_{5}$ & & 48.02 & 64.87 & 40.82 \\
\hline $\mathrm{T}_{6}$ & & 49.16 & 66.27 & 41.87 \\
\hline Mean & & 47.58 & 64.11 & 41.37 \\
\hline Varieties & & 45 DAS & $60 \mathrm{DAS}$ & $90 \mathrm{DAS}$ \\
\hline $\mathrm{V}_{1}$ & & 44.05 & 58.92 & 36.5 \\
\hline $\mathrm{V}_{2}$ & & 46.9 & 62.84 & 41.65 \\
\hline $\mathrm{V}_{3}$ & & 47.37 & 63.12 & 37.88 \\
\hline $\mathrm{V}_{4}$ & & 48.5 & 65.31 & 42.04 \\
\hline $\mathrm{V}_{5}$ & & 51.17 & 70.37 & 48.88 \\
\hline Mean & & 47.59 & 54.85 & 41.39 \\
\hline DAS & & SE(m) \pm & C.D. at 5\% & CV\% \\
\hline \multirow{4}{*}{45} & $\bar{V}$ & 0.138 & 0.449 & 1.33 \\
\hline & $\mathrm{T}$ & 0.107 & 0.302 & 0.87 \\
\hline & VxT & 0.202 & 0.595 & \\
\hline & $\mathrm{TxV}$ & 0.239 & 0.675 & \\
\hline \multirow{4}{*}{60} & $\bar{V}$ & 0.118 & 0.384 & 0.84 \\
\hline & $\mathrm{T}$ & 0.119 & 0.336 & 0.72 \\
\hline & VxT & 0.211 & 0.614 & \\
\hline & $\mathrm{TxV}$ & 0.265 & 0.751 & \\
\hline \multirow{4}{*}{90} & $\mathrm{~V}$ & 0.132 & 0.446 & 1.37 \\
\hline & $\mathrm{T}$ & 0.103 & 0.301 & 0.83 \\
\hline & VxT & 0.204 & 0.593 & \\
\hline & $\mathrm{TxV}$ & 0.234 & 0.674 & \\
\hline
\end{tabular}


Table.9 Effect of NAA, GA3 and IAA on total dry matter per plant (g) of different sesame cultivars

\begin{tabular}{|c|c|c|c|c|}
\hline Treatment & & 45 DAS & 60 DAS & 90 DAS \\
\hline $\mathrm{T}_{0}$ & & 1.64 & 3.64 & 7.47 \\
\hline $\mathrm{T}_{1}$ & & 1.66 & 3.75 & 7.74 \\
\hline $\mathrm{T}_{2}$ & & 1.9 & 3.92 & 8.04 \\
\hline $\mathrm{T}_{3}$ & & 1.77 & 3.72 & 7.74 \\
\hline $\mathrm{T}_{4}$ & & 1.81 & 3.9 & 8.01 \\
\hline $\mathrm{T}_{5}$ & & 1.77 & 3.78 & 7.77 \\
\hline $\mathrm{T}_{6}$ & & 1.93 & 4.09 & 8.43 \\
\hline Mean & & 1.78 & 3.82 & 7.88 \\
\hline Varieties & & 45 DAS & $60 \mathrm{DAS}$ & $90 \mathrm{DAS}$ \\
\hline $\mathrm{V}_{1}$ & & 1.58 & 3.87 & 7.41 \\
\hline $\mathrm{V}_{2}$ & & 1.89 & 3.98 & 8.12 \\
\hline $\mathrm{V}_{3}$ & & 1.68 & 3.84 & 7.65 \\
\hline $\mathrm{V}_{4}$ & & 1.81 & 3.92 & 7.86 \\
\hline $\mathrm{V}_{5}$ & & 1.98 & 4.16 & 8.39 \\
\hline Mean & & 1.78 & 3.95 & 7.88 \\
\hline DAS & & $\mathrm{SE}(\mathrm{m}) \pm$ & C.D. & CV\% \\
\hline \multirow{4}{*}{45} & $\mathrm{~V}$ & 0.026 & 0.086 & 6.758 \\
\hline & $\mathrm{T}$ & 0.017 & 0.049 & 3.754 \\
\hline & VxT & 0.034 & 0.103 & \\
\hline & $\mathrm{TxV}$ & 0.038 & 0.109 & \\
\hline \multirow{4}{*}{60} & $\mathrm{~V}$ & 0.02 & 0.06 & 2.42 \\
\hline & $\mathrm{T}$ & 0.024 & 0.07 & 2.5 \\
\hline & VxT & 0.042 & 0.123 & \\
\hline & $\mathrm{TxV}$ & 0.055 & 0.157 & \\
\hline \multirow{4}{*}{90} & $\mathrm{~V}$ & 0.018 & 0.059 & 1.06 \\
\hline & $\mathrm{T}$ & 0.016 & 0.047 & 0.828 \\
\hline & VxT & 0.03 & 0.089 & \\
\hline & $\mathrm{TxV}$ & 0.037 & 0.106 & \\
\hline
\end{tabular}


Table.10 Effect of NAA, GA3 and IAA on LAI, LAR, RGR of different sesame cultivars

\begin{tabular}{|c|c|c|c|c|}
\hline Treatments & & LAI & $\begin{array}{c}\text { LAR } \\
(\mathrm{cm} 2 / \mathrm{g})\end{array}$ & $\begin{array}{c}\text { RGR } \\
\text { (g/g/day) }\end{array}$ \\
\hline $\mathrm{T}_{0}$ & & 0.092 & 75.36 & 1.573 \\
\hline $\mathrm{T}_{1}$ & & 0.095 & 77.48 & 1.596 \\
\hline $\mathrm{T}_{2}$ & & 0.096 & 78.66 & 1.607 \\
\hline $\mathrm{T}_{3}$ & & 0.093 & 77.28 & 1.606 \\
\hline $\mathrm{T}_{4}$ & & 0.094 & 78.33 & 1.627 \\
\hline $\mathrm{T}_{5}$ & & 0.094 & 78.91 & 1.623 \\
\hline $\mathrm{T}_{6}$ & & 0.097 & 79.7 & 1.654 \\
\hline \multicolumn{5}{|c|}{ Varieties } \\
\hline $\mathrm{V}_{1}$ & & 0.58 & 77.53 & 1.499 \\
\hline $\mathrm{V}_{2}$ & & 0.72 & 80.93 & 1.677 \\
\hline $\mathrm{V}_{3}$ & & 0.60 & 78.52 & 1.531 \\
\hline $\mathrm{V}_{4}$ & & 0.67 & 78.62 & 1.601 \\
\hline V5 & & 0.78 & 82.65 & 1.750 \\
\hline DAS & & $\mathrm{SE}(\mathrm{m}) \pm$ & C.D.at 5\% & CV\% \\
\hline \multirow{4}{*}{ LAI } & V & 0.01 & 0.01 & 1.09 \\
\hline & $\mathrm{T}$ & 0.01 & 0.001 & 1.23 \\
\hline & VxT & 0.001 & 0.001 & \\
\hline & $\mathrm{TxV}$ & 0.001 & 0.002 & \\
\hline \multirow{4}{*}{ LAR } & V & 0.035 & 0.115 & 2.04 \\
\hline & $\mathrm{T}$ & 0.021 & 0.06 & 1.04 \\
\hline & VxT & 0.044 & 0.132 & \\
\hline & $\mathrm{TxV}$ & 0.048 & 0.135 & \\
\hline \multirow{4}{*}{ RGR } & V & 0.009 & 0.03 & 2.66 \\
\hline & $\mathrm{T}$ & 0.02 & 0.05 & 4.9 \\
\hline & VxT & 0.033 & 0.095 & \\
\hline & $\mathrm{TxV}$ & 0.045 & 0.129 & \\
\hline
\end{tabular}


Table.11 Effect of NAA, GA 3 and IAA on LWR, SLW, SLA of different Sesame cultivars

\begin{tabular}{|c|c|c|c|c|}
\hline Treatments & \multicolumn{2}{|c|}{$\operatorname{LWR}(g / g)$} & $\begin{array}{c}\text { SLW } \\
\left(\mathrm{g} / \mathrm{dm}^{2}\right) \\
\end{array}$ & $\begin{array}{c}\text { SLA } \\
\left(\mathrm{dm}^{2} / \mathrm{g}\right)\end{array}$ \\
\hline $\mathrm{T}_{0}$ & \multicolumn{2}{|c|}{0.539} & 0.151 & 1.490 \\
\hline $\mathrm{T}_{1}$ & \multicolumn{2}{|c|}{0.549} & 0.151 & 1.484 \\
\hline $\mathrm{T}_{2}$ & \multicolumn{2}{|c|}{0.559} & 0.220 & 1.464 \\
\hline $\mathrm{T}_{3}$ & \multicolumn{2}{|c|}{0.532} & 0.156 & 1.488 \\
\hline $\mathrm{T}_{4}$ & \multicolumn{2}{|c|}{0.542} & 0.226 & 1.446 \\
\hline $\mathrm{T}_{5}$ & \multicolumn{2}{|c|}{0.545} & 0.192 & 1.468 \\
\hline $\mathrm{T}_{6}$ & \multicolumn{2}{|c|}{0.576} & 0.238 & 1.434 \\
\hline \multicolumn{5}{|c|}{ Varieties } \\
\hline $\mathrm{V}_{1}$ & \multicolumn{2}{|c|}{0.493} & 0.149 & 1.505 \\
\hline $\mathrm{V}_{2}$ & \multicolumn{2}{|c|}{0.567} & 0.269 & 1.5457 \\
\hline $\mathrm{V}_{3}$ & \multicolumn{2}{|c|}{0.552} & 0.159 & 1.473 \\
\hline $\mathrm{V}_{4}$ & \multicolumn{2}{|c|}{0.538} & 0.215 & 1.463 \\
\hline $\mathrm{V}_{5}$ & \multicolumn{2}{|c|}{0.595} & 0.298 & 1.437 \\
\hline DAS & & $\mathrm{SE}(\mathrm{m}) \pm$ & C.D.at 5\% & $\mathrm{CV} \%$ \\
\hline \multirow{4}{*}{ LWR } & V & 0.008 & 0.026 & 6.833 \\
\hline & $\mathrm{T}$ & 0.007 & 0.021 & 5.41 \\
\hline & VxT & 0.013 & 0.04 & \\
\hline & $\mathrm{TxV}$ & 0.017 & 0.048 & \\
\hline \multirow{4}{*}{ SLW } & V & 0.064 & 0.211 & 15.19 \\
\hline & $\mathrm{T}$ & 0.044 & 0.124 & 9.17 \\
\hline & VxT & 0.086 & 0.257 & \\
\hline & $\mathrm{TxV}$ & 0.098 & 0.278 & \\
\hline \multirow{4}{*}{ SLA } & V & 0.096 & 0.314 & 3.012 \\
\hline & $\mathrm{T}$ & 0.089 & 0.252 & 2.35 \\
\hline & VxT & 0.161 & 0.471 & \\
\hline & $\mathrm{TxV}$ & 0.199 & 0.564 & \\
\hline
\end{tabular}


Table.12 Effect of NAA, GA3 and IAA on CGR, LAD, NAR of different sesame

\begin{tabular}{|c|c|c|c|c|}
\hline Treatments & & $\begin{array}{c}\text { CGR } \\
\text { (g/m /day) } \\
\end{array}$ & $\begin{array}{l}\text { LAD } \\
\text { (Days) }\end{array}$ & $\begin{array}{c}\text { NAR } \\
\left(\mathrm{mg} / \mathrm{dm}^{2} / \text { day }\right)\end{array}$ \\
\hline $\mathrm{T}_{0}$ & & 45.39 & 32.52 & 72.3 \\
\hline $\mathrm{T}_{1}$ & & 47.59 & 35.85 & 75.6 \\
\hline $\mathrm{T}_{2}$ & & 49.85 & 36.75 & 92.9 \\
\hline $\mathrm{T}_{3}$ & & 47.59 & 37.07 & 85.9 \\
\hline $\mathrm{T}_{4}$ & & 51.81 & 37.11 & 93.3 \\
\hline $\mathrm{T}_{5}$ & & 48.52 & 36.08 & 93.1 \\
\hline $\mathrm{T}_{6}$ & & 52.09 & 36.56 & 105.7 \\
\hline \multicolumn{5}{|c|}{ Varieties } \\
\hline $\mathrm{V}_{1}$ & & 46.80 & 32.27 & 68.2 \\
\hline $\mathrm{V}_{2}$ & & 48.60 & 39.65 & 95.0 \\
\hline $\mathrm{V}_{3}$ & & 47.43 & 35.00 & 67.4 \\
\hline $\mathrm{V}_{4}$ & & 47.48 & 36.45 & 72.6 \\
\hline $\mathrm{V}_{5}$ & & 48.91 & 40.58 & 97.4 \\
\hline DAS & & $\mathrm{SE}(\mathrm{m}) \pm$ & C.D.at 5\% & CV\% \\
\hline \multirow{4}{*}{ CGR } & V & 0.005 & 0.018 & 5.31 \\
\hline & $\mathrm{T}$ & 0.002 & 0.005 & 16.53 \\
\hline & VxT & 0.005 & 0.016 & \\
\hline & $\mathrm{TxV}$ & 0.004 & 0.012 & \\
\hline \multirow{4}{*}{ LAD } & V & 0.038 & 0.125 & 4.91 \\
\hline & $\mathrm{T}$ & 0.034 & 0.097 & 3.721 \\
\hline & VxT & 0.063 & 0.184 & \\
\hline & $\mathrm{TxV}$ & 0.077 & 0.218 & \\
\hline \multirow{4}{*}{ NAR } & $\mathrm{V}$ & 0.0001 & 0.0005 & 7.94 \\
\hline & $\mathrm{T}$ & 0.0002 & 0.0005 & 7.86 \\
\hline & $\mathrm{VxT}$ & 0.0003 & 0.001 & \\
\hline & $\mathrm{TxV}$ & 0.0004 & 0.0001 & \\
\hline
\end{tabular}


Table.13 Effect of NAA, GA3 and IAA on No. of capsules per plant and no. of seeds per capsule of different sesame cultivars

\begin{tabular}{|c|c|c|c|c|}
\hline Treatments & \multicolumn{2}{|c|}{ No. of capsules/plant } & \multicolumn{2}{|c|}{ No. of seeds/capsule } \\
\hline $\mathrm{T}_{0}$ & & 16.94 & & 40.54 \\
\hline $\mathrm{T}_{1}$ & & 17.04 & & 40.88 \\
\hline $\mathrm{T}_{2}$ & & 17.22 & & 41.02 \\
\hline $\mathrm{T}_{3}$ & & 17.18 & & 40.9 \\
\hline $\mathrm{T}_{4}$ & & 17.34 & & 41.14 \\
\hline $\mathrm{T}_{5}$ & & 17.26 & & 40.98 \\
\hline $\mathrm{T}_{6}$ & & 17.64 & & 41.08 \\
\hline MEAN & & 17.23 & & 40.93 \\
\hline \multicolumn{5}{|c|}{ VARIETIES } \\
\hline $\mathrm{V}_{1}$ & & 16.84 & & 38.65 \\
\hline $\mathrm{V}_{2}$ & & 18.0 & & 43.14 \\
\hline $\mathrm{V}_{3}$ & & 16.07 & & 37.8 \\
\hline $\mathrm{V}_{4}$ & & 16.87 & & 40.81 \\
\hline $\mathrm{V}_{5}$ & & 18.37 & & 44.25 \\
\hline MEAN & & 17.23 & & 40.93 \\
\hline DAS & & $\mathrm{SE}(\mathbf{m}) \pm$ & $\begin{array}{c}\text { C.D. at } \\
5 \%\end{array}$ & $\mathrm{CV}$ \\
\hline \multirow{4}{*}{$\begin{array}{l}\text { No. of } \\
\text { capsules/plant }\end{array}$} & $\mathrm{V}$ & 0.033 & 0.107 & 0.88 \\
\hline & $\mathrm{T}$ & 0.045 & 0.126 & 1.0 \\
\hline & VxT & 0.076 & 0.218 & \\
\hline & $\mathrm{TxV}$ & 0.1 & 0.281 & \\
\hline \multirow{4}{*}{ No. of seeds/capsule } & $\mathrm{V}$ & 0.022 & 0.07 & 0.24 \\
\hline & $\mathrm{T}$ & 0.012 & 0.034 & 0.12 \\
\hline & VxT & 0.026 & 0.077 & \\
\hline & $\mathrm{TxV}$ & 0.027 & 0.077 & \\
\hline
\end{tabular}


Table.14 Effect of NAA, GA3 and IAA on no. of chaffy seeds per capsule and no. of healthy seeds per capsule of different sesame cultivars

\begin{tabular}{|c|c|c|c|c|}
\hline Treatments & \multicolumn{2}{|c|}{ No. of chaffy seeds/capsule } & \multicolumn{2}{|c|}{$\begin{array}{l}\text { No. of healthy } \\
\text { seeds/capsule }\end{array}$} \\
\hline $\mathrm{T}_{0}$ & & 3.1 & \multicolumn{2}{|c|}{30.32} \\
\hline $\mathrm{T}_{1}$ & & 2.9 & \multicolumn{2}{|c|}{34.14} \\
\hline $\mathrm{T}_{2}$ & & .72 & \multicolumn{2}{|c|}{34.54} \\
\hline $\mathrm{T}_{3}$ & & .46 & \multicolumn{2}{|c|}{31.08} \\
\hline $\mathrm{T}_{4}$ & & 4.2 & \multicolumn{2}{|c|}{33.6} \\
\hline $\mathrm{T}_{5}$ & & .46 & \multicolumn{2}{|c|}{29.48} \\
\hline $\mathrm{T}_{6}$ & & .56 & \multicolumn{2}{|c|}{33.2} \\
\hline MEAN & & .05 & \multicolumn{2}{|c|}{32.33} \\
\hline \multicolumn{5}{|c|}{ VARIETIES } \\
\hline $\mathrm{V}_{1}$ & & 5.4 & \multicolumn{2}{|c|}{29.82} \\
\hline $\mathrm{V}_{2}$ & & 4.8 & \multicolumn{2}{|c|}{34.57} \\
\hline $\mathrm{V}_{3}$ & & .68 & \multicolumn{2}{|c|}{29.82} \\
\hline $\mathrm{V}_{4}$ & & .04 & \multicolumn{2}{|c|}{31.11} \\
\hline $\mathrm{V}_{5}$ & & .35 & \multicolumn{2}{|c|}{36.34} \\
\hline MEAN & & .05 & \multicolumn{2}{|c|}{32.33} \\
\hline DAS & & $\mathrm{SE}(\mathbf{m}) \pm$ & C.D. at $5 \%$ & CV \\
\hline \multirow{4}{*}{$\begin{array}{l}\text { No. of chaffy } \\
\text { seeds/capsule }\end{array}$} & $\mathrm{V}$ & 0.037 & 0.119 & 3.31 \\
\hline & $\mathrm{T}$ & 0.029 & 0.083 & 2.25 \\
\hline & VxT & 0.055 & 0.162 & \\
\hline & $\mathrm{TxV}$ & 0.066 & 0.186 & \\
\hline \multirow{4}{*}{$\begin{array}{l}\text { No. of Healthy } \\
\text { seeds/capsule }\end{array}$} & $\mathrm{V}$ & 0.533 & 1.739 & 7.56 \\
\hline & $\mathrm{T}$ & 0.695 & 1.965 & 8.32 \\
\hline & VxT & 1.188 & 3.422 & \\
\hline & $\mathrm{TxV}$ & 1.553 & 4.393 & \\
\hline
\end{tabular}


Table.15 Effect of NAA, GA3 and IAA on 1000 seed weight, yield and oil content of different sesame cultivars

\begin{tabular}{|c|c|c|c|c|}
\hline Treatments & \multicolumn{2}{|c|}{1000 seed weight } & Yield & Oil content $(\%)$ \\
\hline $\mathrm{T}_{0}$ & \multicolumn{2}{|r|}{2.92} & 4.0 & 46.62 \\
\hline $\mathrm{T}_{1}$ & \multicolumn{2}{|r|}{3.12} & 4.44 & 48.13 \\
\hline $\mathrm{T}_{2}$ & \multicolumn{2}{|r|}{3.08} & 4.78 & 48.86 \\
\hline $\mathrm{T}_{3}$ & \multicolumn{2}{|r|}{3.16} & 4.02 & 48.23 \\
\hline $\mathrm{T}_{4}$ & \multicolumn{2}{|r|}{3.24} & 4.96 & 48.43 \\
\hline $\mathrm{T}_{5}$ & \multicolumn{2}{|r|}{3.14} & 4.36 & 48.37 \\
\hline $\mathrm{T}_{6}$ & \multicolumn{2}{|r|}{3.12} & 4.8 & 48.92 \\
\hline MEAN & \multicolumn{2}{|r|}{3.14} & 4.48 & 48.22 \\
\hline \multicolumn{5}{|c|}{ Varieties } \\
\hline $\mathrm{V}_{1}$ & \multicolumn{2}{|r|}{3.01} & 3.24 & 54.61 \\
\hline $\mathrm{V}_{2}$ & \multicolumn{2}{|r|}{3.07} & 5.08 & 46.03 \\
\hline $\mathrm{V}_{3}$ & \multicolumn{2}{|r|}{2.98} & 3.84 & 49.19 \\
\hline $\mathrm{V}_{4}$ & \multicolumn{2}{|r|}{3.2} & 4.62 & 45.95 \\
\hline $\mathrm{V}_{5}$ & \multicolumn{2}{|r|}{3.4} & 5.6 & 45.33 \\
\hline MEAN & \multicolumn{2}{|r|}{3.14} & 4.48 & 48.22 \\
\hline DAS & & $\mathrm{SE}(\mathrm{m}) \pm$ & C.D. at $5 \%$ & CV\% \\
\hline \multirow{4}{*}{1000 seed weight } & $\mathrm{V}$ & 0.017 & 0.056 & 2.5 \\
\hline & $\mathrm{T}$ & 0.016 & 0.044 & 1.91 \\
\hline & VxT & 0.028 & 0.083 & \\
\hline & $\mathrm{TxV}$ & 0.035 & 0.098 & \\
\hline \multirow{4}{*}{ Yield } & $\mathrm{V}$ & 0.314 & 1.023 & 32.09 \\
\hline & $\mathrm{T}$ & 0.170 & 0.482 & 14.72 \\
\hline & VxT & 0.365 & 1.104 & \\
\hline & $\mathrm{TxV}$ & 0.38 & 1.07 & \\
\hline \multirow{4}{*}{ Oil content (\%) } & $\mathrm{V}$ & 0.031 & 0.101 & 0.295 \\
\hline & $\mathrm{T}$ & 0.026 & 0.075 & 0.215 \\
\hline & VxT & 0.049 & 0.144 & \\
\hline & $\overline{\mathrm{TxV}}$ & 0.059 & 0.169 & \\
\hline
\end{tabular}


Table.16 Correlation coefficient matrix between physiological growth parameters with yield and its attributing characters

\begin{tabular}{|c|c|c|c|c|c|c|c|c|c|}
\hline & Yield & $\begin{array}{c}\text { No of } \\
\text { capsules per } \\
\text { plant }\end{array}$ & $\begin{array}{c}\text { No of } \\
\text { seeds per } \\
\text { capsule }\end{array}$ & $\begin{array}{c}\text { No of } \\
\text { chaffy } \\
\text { seeds per } \\
\text { capsule } \\
\end{array}$ & $\begin{array}{c}\text { No of } \\
\text { healthy } \\
\text { seeds per } \\
\text { capsule } \\
\end{array}$ & $\begin{array}{l}1000 \text { seed } \\
\text { weight }\end{array}$ & $\begin{array}{l}\text { Oil content } \\
\text { percentage }\end{array}$ & $\begin{array}{c}\text { Plant height } \\
\text { (90 DAS) }\end{array}$ & $\begin{array}{c}\text { Total } \\
\text { dry } \\
\text { matter }\end{array}$ \\
\hline Yield & - & 0.820 & 0.936 & -0.904 & 0.924 & 0.8 & -0.904 & -0.636 & 0.990 \\
\hline LAI & 0.984 & 0.898 & 0.974 & -0.959 & 0.968 & 0.840 & -0.831 & -0.514 & 0.989 \\
\hline CGR & 0.946 & 0.852 & 0.911 & -0.854 & 0.964 & 0.667 & -0.804 & -0.656 & 0.973 \\
\hline RGR & 0.981 & 0.9 & 0.969 & -0.95 & 0.978 & 0.820 & -0.822 & -0.529 & 0.993 \\
\hline NAR & 0.893 & 0.956 & 0.958 & -0.909 & 0.986 & 0.645 & -0.669 & -0.489 & 0.922 \\
\hline SLW & 0.978 & 0.92 & 0.986 & -0.956 & 0.975 & 0.784 & -0.819 & -0.537 & 0.980 \\
\hline SLA & -0.236 & 0.038 & -0.065 & 0.208 & -0.1001 & -0.650 & 0.264 & -0.126 & -0.249 \\
\hline LWR & 0.897 & 0.625 & 0.743 & -0.694 & 0.828 & 0.648 & -0.857 & -0.745 & 0.922 \\
\hline LAR & 0.927 & 0.881 & 0.915 & -0.892 & 0.980 & 0.754 & -0.733 & -0.514 & 0.968 \\
\hline LAD & 0.983 & 0.821 & 0.921 & -0.862 & 0.937 & 0.700 & -0.892 & -0.709 & 0.986 \\
\hline $\begin{array}{c}\text { Total } \\
\text { Chlorophyll } \\
\text { content }\end{array}$ & 0.845 & 0.936 & 0.918 & -0.948 & 0.960 & 0.844 & -0.565 & -0.216 & 0.893 \\
\hline $\begin{array}{l}\text { Plant height } \\
\text { (90 DAS) }\end{array}$ & -0.636 & -0.242 & -0.421 & 0.272 & -0.447 & -0.115 & 0.812 & - & \\
\hline $\begin{array}{c}\text { Total dry } \\
\text { matter }\end{array}$ & - & 0.847 & 0.939 & -0.911 & 0.956 & 0.804 & -0.868 & -0.604 & - \\
\hline
\end{tabular}


The leaf area duration between 60 to 90 DAS was calculated and reflected in table 12. From the data it was revealed that the highest LAD (37.11 Days) was recorded from $\mathrm{GA}_{3} 20$ ppm conc. which is $14.11 \%$ increase over the control. Among the varieties highest value of LAD was observed in Nirmala (40.58) but the minimum value was shown in Uma (32.27). The interaction effect between the LAD and the yield was found to be significant. LAD is positively correlated with yield $(r=0.983)$ (Table 16).

The leaf area index (LAI) was increased significantly irrespective of varieties due to foliar spray of plant growth regulators. There was remarkable improvement in LAI with $15.78 \%$ decreases at 90 DAS of the crop on $\mathrm{GA}_{3} 20 \mathrm{ppm}$ conc. The findings was close conformity with the result of Barun and wild (1984), similar trend was recorded in relative growth rate (RGR) as the leaf area was increased the photosynthetic rate was increased which enhance the growth rate, higher concentration of PGRs contributed higher RGR. The net assimilation rate is a measure of photosynthesis of leaves in crop community due to optimum LAI net assimilation rate (NAR) was found maximum in IAA $20 \mathrm{ppm}$ conc. (105.7 $\mathrm{mg} / \mathrm{dm}^{2} /$ day) so NAR significantly influenced by hormonal manipulation (Briggs et al., 1920). Specific leaf weight a measure of leaf thickness has been reported a strong positive correlation with photosynthesis of several crops as reported by Bowes et al., (1972).

Thicker leaves would have more number of mesophyll cells with a high density of chlorophyll for which they have the greater photosynthetic capacity. PGRs increased leaf area with more chlorophyll content which ultimately more SLW, IAA 20 ppm exhibited more SLW. Higher SLW might be associated with higher cell surface to volume ratio. The foliar spraying of PGRs increased SLW of sesame. The present findings are in close conformity of Dornhoff and Sibles (1970). The product of NAR and LAI resulted in CGR which was found higher in all the treatments of PGRs over the control. CGR has a strong positive correlation with LAI as the LAI was found maximum in PGRs treated plots the CGR was noted highest in IAA 20 ppm conc. (52.09 $\mathrm{g} / \mathrm{m}^{2} /$ day) so from the present study concluded that foliar application PGRs significantly expressed the higher values of growth attributes viz. LAI, CGR, NAR and SLW by showing higher accumulation of total dry matter production with increased yield.

\section{Yield and yield attributing characters}

The yield of a crop depends upon the yielding potentiality of the variety but it is governed by the environmental factors around the crop. The yield and the yield attributing character affected by growth regulators were recorded, analyzed and presented in the following subheads.

\section{Number of capsules per plant}

The number of capsules per plant due to the effect of growth regulators has been computed in table 13. From the data it was revealed that irrespective of varieties there was an increase of number of capsules per plant due to the application of growth regulators. Among the varieties Nirmala exhibited the highest number of capsule per plant (18.37) followed by Amrit (18.0) whereas lowest value was recorded from Smarak (16.07).Among the treatments highest number of capsules was produced (17.64) by the effect of IAA @20 ppm followed by $\mathrm{GA}_{3}$ @ 20 ppm (17.34) which is $4.13 \%$ and $2.36 \%$ increased over the control. It was found that significant difference was noted among the varieties and treatments. The interaction effect between treatments and varieties was 
not significant. There was positive correlation between the yield and the number of capsules per plant $(\mathrm{r}=0.820)$ (Table 16).

\section{Number of seeds per capsule}

Data computed in table 13 revealed that the number of seeds per capsule was not much more affected by growth regulator and the percentage of increase in seed ranged from 0.83 in NAA @ 10 ppm to 1.48 in $\mathrm{GA}_{3} @ 20$ ppm. Among the treatments GA @20ppm contributed highest number of seeds per capsules per capsule (41.44) followed by IAA @20 ppm treatment (41.08) whereas the lowest value was recorded from control (40.54). Among the varieties the highest number of seeds was contributed by Nirmala (44.25) followed by Amrit (43.14) whereas lowest value of the same was noted from Smarak (37.80) significant difference among the varieties was noted. There was positive correlation between yield and Number of healthy seeds per capsule $(r=0.936)$ (Table 16).

\section{Number of healthy seeds per capsule}

Data recorded in table 14 indicated that application growth regulator increased the filled up grains per capsule in all the varieties. The maximum filled up grains was recorded from NAA @20 ppm (34.54) followed by NAA 10 ppm (34.14) which was (15.80\%) and $(17.16 \%)$ increased over the control. Among the varieties Nirmala contributed the highest number of healthy seeds (36.34) followed by Amrit (34.57) whereas the minimum value of the same was exhibited by Uma and Smarak (29.82 kg). Significance difference among the varieties was noted as per the C.V value there was greater variation among the treatment and varieties as recorded to number of healthy seeds. There was positive correlation between yield and number of healthy seeds per capsule $(r=0.924)$ (Table 16).

\section{Number of chaffy seeds/capsules}

From the data computed in table 14 revealed that the number of chaffy seeds decreased irrespective of varieties. Highest number of chaffy seeds per capsules was recorded by control (8.1) whereas the minimum value of the same was noted from NAA@20 ppm (2.72) followed by NAA @ 10 ppm (2.9). It was found that highest number of chaffy seeds were exhibited by Smarak (5.68) followed by Uma (5.40) but minimum value of the same was recorded from Nirmala (4.35).It was noted that significant difference was found among the treatment as well as among the varieties. The interaction effect between the variety and treatment was significant. There was negative correlation between yield and chaffy seed $(r=-0.904)$ (Table 16).

\section{0 seed weight}

One thousand seed weight have been depicted in table 15. From the data it was found that among the cultivars the highest test weight was recorded from Nirmala (3.40 g) followed by Prachi $(3.20 \mathrm{~g})$ whereas the lowest value at the same was noted in Smarak (2.98 g) Irrespective of treatment. There was increased of 1000 seed weight on compared to the control. The percentage of increase ranged from 6.84 in NAA 10 ppm to 10.95 in $\mathrm{GA}_{3} 20$ ppm. A significantly difference among the varieties and treatments were noted. There was positive correlation between yield and 100 seed test weight $(r=0.8)$ (Table 16).

\section{Yield}

The yield data is compared in table 15 which reflected that the highest yield was contributed by Nirmala ( $5.6 \mathrm{q} / \mathrm{ha}$ ) followed by Amrit (5.08 q/ha) but the lowest yield was exhibited by Uma (3.24 q/ha) among all the varieties due to the effect of growth regulators. Due to the effect of growth 
regulator maximum yield was produced due to spraying IAA @20 ppm (4.80 q/ha) followed by NAA @20 ppm (4.78 q/ha) whereas the minimum yield was exhibited by $\mathrm{GA}_{3} @ 10 \mathrm{ppm}$. The percentage of increase of yield ranged from 0.5 in $\mathrm{GA}_{3} @ 10 \mathrm{ppm}$ conc. to IAA@20 ppm conc. $20 \%$. A significant difference between the variety and treatment was noted. The interaction effect as regards to yield is non-significant.

\section{Oil content of seeds (\%)}

Analysis of oil content of seeds table 15 revealed that irrespective of variety the oil content of seeds was increased, ranging from $3.23 \%$ in NAA $10 \mathrm{ppm}$ conc. to $4.93 \%$ IAA $20 \mathrm{ppm}$ conc. In Significant difference among the treatments was noted as regards to oil content of the seeds. Among the varieties Uma contributed highest oil content (54.61 $\%)$ followed by Smarak (49.19 \%) whereas the lowest value of the same was recorded from Nirmala $(45.33 \%)$. Significant difference in respect to oil content among the varieties was noted. The interaction effect between the variety and treatment was found. There was negative correlation between the yield and oil content of the seeds $(r=-0.0904)$ (Table 16).

The response in yield and yield attributing characters were studied under different concentration of NAA, GA3, IAA. Increase in seed yield over the control ranged from $0.5 \%$ in $\mathrm{GA}_{2} 10 \mathrm{ppm}$ to $24 \%$ in $\mathrm{GA}_{3} 20 \mathrm{ppm}$ conc. more or less similar increase in number of capsules number of seeds per capsules and 1000 seed weight was observed in PGRs treatments over the control. Similar effects of growth substances were obtained by Akhtar $e t$ al., (1998).

From the present investigation it was concluded that there is a remarkable effect of NAA, IAA and $\mathrm{GA}_{3}$ improving the oil content of seeds. Both the concentration of all the growth regulators significantly increased the oil content over the control. The oil content of seeds increased to an extent of $3.23 \%$ in NAA $10 \mathrm{ppm}$ to $4.9 \%$ in IAA $20 \mathrm{ppm}$ conc. This finding confirms the findings of previous workers (Akhtar et al., 1998).

It can be concluded that application of Plant growth regulators of different concentration increased plant height irrespective of varieties and the maximum plant height was observed in $\mathrm{GA}_{3} 20 \mathrm{ppm}(138.4 \mathrm{~cm})$ followed by $\mathrm{GA}_{3} 10 \mathrm{ppm}(134.59 \mathrm{~cm})$ Among the varieties the maximum increase in plant height was recorded from Nirmala followed by Prachi. Exogenous spraying of growth regulators significantly increasing the oil content of seeds irrespective of varieties over the control. The percentage of increase ranged from 3.23 in NAA $10 \mathrm{ppm}$ conc. to $4.9 \%$ in IAA 20 ppm conc. whereas among the varieties the highest percentage of oil content was recorded from Uma (54.61\%) followed by Smarak $(49.19 \%)$. The application of $\mathrm{GA}_{3}$ $20 \mathrm{ppm}$ concentration contributed highest profit $(104.76 \%)$ followed by IAA $20 \mathrm{ppm}$ concentration $(20.8 \%)$ whereas NAA in both concentration along with a lower concentration of IAA and $\mathrm{GA}_{3}$ have no effect on profit.

\section{References}

Agrawal, S. and Dikshit, S.N. (2008). Studies on the effect of plant growth regulators on growth and yield of sapota (Achras sapota L.) cv. cricket ball. Indian J. Agric. Res. 42(3): 207 -211.

Akhtar, N. (1998). Ann. Bangladesh Agric. 6(1): 67-70.

Araby, E.l., Hawasha, R. S., Diwania, G. (2009). Treatment of iron and manganese in simulated groundwater via ozone technology. Desalination. 249(3): 1345-1349. 
Araby, M.M., S.M.A. Mostafa, A.I. Ismail and A.Z.A. Hegazi. (2006). Hormone and phenol levels during germination and osmopriming of tomato seeds and associated variations in portion patterns and anatomical seed features. Acta Agron. Hungarica. 54: 441-457.

Awan, I. and H.K. Alizai. (1989). Effect of plant growth regulators on ripening, grain development and rice quality. Int. Rice Res. Newsletter, 149: 30-31.

Bowes, G.W., Orgen, L., and Hageman, R. H. (1972). Light saturated photosynthesis rate, RuBp Carboxylase activity and specific leaf weight in soybean grown under different light intensities. Crop Sci. 12: 77-79.

Braun, P. and Wild, M. (1984). The influence of brassinosteroid on growth and parameters of photosynthesis of wheat and mustard plants. J. Plant Physiol. 116: $189-196$

Briggs, G.E., Kidd, F. and West, C. (1920). A quantitative analysis of plant growth. Pt. Int. Ann. Appli Biol.7: 103.

Chauhan, J.S. (2009). Journal of American Society. 5(5):79-84.

Deotale, R.D., Maske, V.G., Sorte, N.V., Chimurkar, B.S. and Yerne, A.Z. (1998). Effect of $\mathrm{GA}_{3}$ and NAA on morpho-physiological parameters of soybean. J. Soils Crops. 8:91-94.

Dornhoff, G.M., and Shibles, R.M. (1970). Varital differences in net photosynthesis of soybean leaves. Crop Sci. 10: 42-45.

Gomez, K.A. and Gomez, A.A. (1984). Statistical procedure for agriculture research $\left(2^{\text {nd }}\right.$ edn.) Jhon Wiley and sons, Inc., New York. 68p.

Gregory, F.G. (1926). Determination of Net Assimilation Rate (NAR). Ann. Bot. 40(165):26.

Gurdev, S. and Saxena, O.P. (1991). Seed treatments with bioregulators in relation to wheat productivity. In New Trends in Plant Physiology, Proceedings of
National Symposium on Growth and Differentiation in Plants New Delhi, India 201-210.

Harrington, J.F., Rappaport, L. and Hood, K.J. (1996). The influence of gibberellins on stem elongation and flowering on endive. Science. 125:601.

Hore, K., Paria, N.C. and Sen., S.K. (1988).Journal of Horticultural Science. 17: 83-87.

Kapgate, H.G., N.N. Potkile, N.G. Zode and A.M. Dhopte, 1989. Persistence of physiological responses of upland cotton to growth regulators. Ann. Plant Physiol., 3: 188-195.

Kokare, R. T., Bhalerao, Prabu, R. K., Chavan, T., Bansode, S. K. and Kachare, G. S. (2006). Effect of plant growth regulators on growth, yield and quality of okra (Abelmoschus esculentus L.). Agricultural Science Digest. 26(3): 178-181.

Kumar, S. and Goel, S.C.(1994). Population dynamics of a pyralid Antigastra catalaunalis Dup on sesame in relation to abiotic factors. Journal Entomological Research. 18(1):61-64.

Kumer, S., Singh, P., Katiyar, R.P., Vaish C.P. and Khan. A.A. (1996). Seed Research $24: 11-14$.

Lalitha, S, Sridhar, K.R. and Sukesh, S. (2015).Seed Dormancy and Germination in Two Wild Genotypes of Sesbania of the Southwest Mangroves in India. International Journal of Agricultural Technology. 11(4):895902.

Lee, H.S. (1990). Effects of pre-sowing seed treatments with $\mathrm{GA}_{3}$ and IAA on flowering and yield components in groundnuts. Korean J. Crop Sci. 35:19.

Leopold, A.C. and Kriedemann, P.E.(1975). Plant Growth and Development. McGraw-Hill Book Co., New York.

Mostafa, G. G. and Hamd, M. F. (2011). 
Effect of gibberellic acid and indole-3 acetic acid on improving growth and accumulation of phytochemical composition in Balanites aegyptica plants. Am. J. Plant physiol. 6: 36-43

Patil, M. S. and Gaikwad D. K. (2011). Effect of plant growth regulators on seed germination of oil yielding plant Simarouba glauca Dc. Plant Sciences Feed. (5): 65- 68.

Sarkar, P.K., Haque, M.S. and Karim, M.A. (2002). Effects of $\mathrm{GA}_{3}$ and IAA and their frequency of application on morphology, yield contributing characters and yield of soybean. Journal of Agronomy. 1:119-122.
Sontakey, P.Y., Patil, B.N., Khorgade, P.W., Bonde and P.W. (1991). Path analysis of some yields attributes in gram. Agric Sci Digest. 11(4): 211-215.

Tian, W. X., Zhao, J.Y., Bai, B.Z., Liu, G.R., Li, M.Y. and Qi, G.Q. (1993). Paclobutrazol affecting yield and quality of sugar beet. Journal of Jilin Agricultural University.15: 97-105.

Watson, D.J. (1937). The estimation of leaf area of field crops. J. Agric. Sci. 27:474-483.

Watson, D.J. (1952). The physiological basis of variation in yield. Adv. Agron., 4: 101-145.

\section{How to cite this article:}

Behera, S., A.K. Padhiary, S. Rout, A. Nayak, D. Behera and Nanda, P.K. 2017. Effect of Plant Growth Regulators on Morpho-Physiological and Yield Parameters of Some Sesame (Sesamum indicum L.) Cultivars. Int.J.Curr.Microbiol.App.Sci. 6(11): 1784-1809.

doi: https://doi.org/10.20546/ijcmas.2017.611.215 